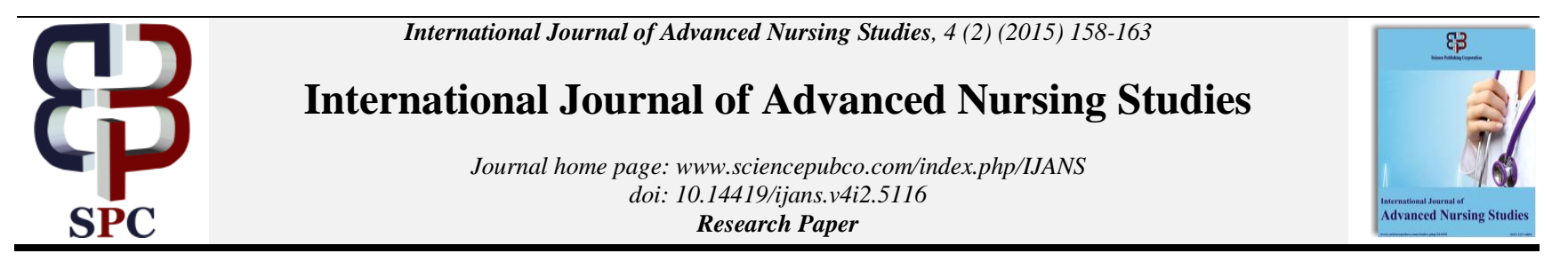

\title{
Model documentation of assessment and nursing diagnosis in the practice of nursing care management for nursing students
}

\author{
A. Aziz Alimul Hidayat ${ }^{1}$, M. Kes * \\ Departement of Nursing, Faculty of Health Sciences, Muhammadiyah University of Surabaya- Indonesia \\ *Corresponding authorE-mail: azizhidayat@yahoo.com
}

\begin{abstract}
Model documentation of assessment and nursing diagnosis in the practice of nursing care management is an integration model in nursing care records, especially records nursing assessment and diagnosis in one format. This model can reduce the duration of the recording in nursing care, and make it easier for students to understand the nursing diagnosis, so that nursing interventions more effective. The purpose of this paper was to describes the form integration documentation of nursing assessment and diagnosis of nursing in nursing care management for nursing students. This literature review was done by searching the following search engine: Pubmed, Midline, EBSCO, and Google Scholar. Data in the synthesis from nursing diagnoses of NANDA-I were incorporated into the of nursing assessment form using Gordon's functional health pattern. Types of articles included: original research, and literature review. This review of article includes 1) introduction 2) form of nursing assessment documentation 3) implementation of nursing diagnosis documentation 4) the implementation strategy documentation of assessment and nursing diagnosis 5) recommendation for nursing education 6) conclusion.
\end{abstract}

Keywords: Nursing Assessment; Nursing Care Managament; Nursing Diagnosis; Nursing Student; and Nursing Documentation.

\section{Introduction}

Nursing assessment and diagnosis are parts of the process in nursing science that allow nurses to solve patient problems. However, if the method does not work effectively, the purpose of the nursing process is not achieved. One reason is that the assessment form and the nursing diagnosis are not integrated, which can reduce the effectiveness of the nursing intervention.

A study done in Indonesia revealed that $50 \%$ of nursing assessment forms did not contain complete information (Sumitra, 2001). Karmawati (2002) also reported that most nursing assessment documents were incomplete, due to the perception that the nursing forms were not appropriate for documenting patient-care needs. Kusumawati (2001) found that nurses who worked at hospitals gained the experience needed to perform diagnoses, while Widyantoro (2002) reported that the documentation process was not capable of capturing the information from nursing diagnoses. These studies demonstrate that little or no effort is being made to integrate the assessment form with nursing diagnosis, and that the implementation of nursing diagnosis in Indonesia according to the North American Nursing Diagnosis Association (NANDA) has not occurred.

Understanding of the NANDA nomenclature is lacking among nurses in Indonesia, even though the implementation of standard language can increase the quality of nursing diagnosis documentation (Muller-Staub M, 2009). The most important obstacles to implementation of nursing diagnosis include the similarity between nurse and doctor assessments and the nurse-to-patient ratio (Paganin et al. 2008). Implementing nursing diagnoses is difficult because the assessment form does not accommodate the nomenclature of NANDA related to nursing diagnosis analysis.

This report describes the strategy for integration of assessment and nursing diagnosis and its effectiveness. Implementation of the two together can increase the quality of nursing and patient care.

\section{Form of nursing assessment documentation}

Assessment is the first step of the nursing process, achieved through data collection or patient interviews. To accomplish this first step, nurses must understand bio-psychosocial concepts, people's spiritual needs, the growth and developmental process, pathophysiology of diseases, family systems and culture, and the value of patient beliefs.

In addition, that nurses need to make systematic observations of patients, communicate verbally and nonverbally, listen well, create effective relationships, build trust, and conduct assessments through interviews or physical examinations.

Reports indicate that nurses can face obstacles when performing diagnostic procedures because of a lack of clarity about proper systems for data analysis. Nursing assessments do not supply a systematic process and the space to record nursing analyses. Most hospitals in Indonesia use the doctor's assessment rather than the nurse's assessment. The contents of the assessment form create difficulties for nurses when they try to record assessment information on the written nursing assessment form. Also, because there is no integration between assessment and nursing diagnosis, incorporating written assessment forms found in the nursing literature is difficult.

Another weakness is the lack of standardized language used in nursing practice and on assessment forms. For example, different 
aspects of nursing use different diagnostic terms for conditions such as hyperthermia. One aspect uses terms such as an increase in body temperature or acute pain. Another uses terms such as feeling good. Still another mentions lack of nutrition or nutritional disorders. These discrepancies, even for a relatively straightforward condition such as hyperthermia, can create problems when nurses examine patients or conduct data analysis. The use of precise and standardized language could reduce misinterpretations and improve the quality of nursing diagnosis (Muller-Staub et al. 2009).

\section{Implementation of nursing diagnosis docu- mentation}

A nursing diagnosis is a clinical judgment about an individual, family, or community response to actual or potential health problems (Herdman, 2008). Nursing diagnosis can provide the basis for the proper intervention. As a part of the nursing obligation, nurses should be competent in assessment and diagnosis procedures. The important nursing diagnosis formula used to identify a complex problem involves investigating the problem etiology and describing signs and symptoms. Nursing diagnosis means actual nursing diagnosis, risk analysis, and identification of syndromes (Herdman, 2008)

To perform a proper diagnosis, a nurse needs knowledge and skills, such as an understanding of potential conditions, possible causative factors, characteristics of the possible conditions, standard measurements used to detect problems, mechanisms of disease processes, critical thinking, and ability to integrate all of the in formation to form a conclusion.

In Indonesia, most nurses understand the medical diagnosis process rather than nursing diagnosis, because no explanation has been provided within the scope of nursing practice. Medical diagnosis explains the process of pathology, while nursing diagnosis explains individual responses of patients to a disease. Medical diagnosis remains relatively constant, but nursing diagnosis is flexible and easily adjusted based on input. Medical diagnosis involves a classification system well accepted by physicians. However, nursing diagnosis has not been widely accepted by the nursing profession. Medical diagnosis also characteristically uses an axis, with the patient condition as the label, then the organ affected, then the location of that organ.

The use of this medical diagnosis axis means that the medical assessment refers to it and that the assessment is done by system (find the system that does not work, assess it in detail, determine whether it influences another system, such as the cardiovascular system). Thus, medical assessment is really designed for medical diagnosis.

It follows that nursing assessment is needed for nursing diagnosis The nursing diagnosis used is based on the response of patients by problem-etiology-symptom (PES) and problem-etiology (PE) formulas. Even these use an axis, the ICNP (International Classification Nursing Practice), but this is not popular in Indonesia Medical diagnosis tends to be similar to that in the U.S., which is based on NANDA-I (North American Nursing Diagnosis Association-International). If nursing diagnosis in Indonesia refers to NANDA-I with a formula (problem, etiology, and symptom; or problem and etiology) based on patient response, the nursing assessments using an approach system will not be relevant. If there is a relation between the two, it will be forced. For example: for a diagnosis of acute pain related to the injury agent, what system can this diagnosis be classified into? Can it be the cardiovascular, neurological, or respiratory system? Because the problem involves pain in all three systems, a diagnosis of hyperthermia is difficult to assign. The experts behind NANDA-I themselves make a link between NANDA-I, and the assessments recommended. Furthermore, in the development of NANDA-I Taxonomy II seven axis were used:

- Axis 1: diagnostic concepts such as activity intolerance, airway clearance, mobility, hope, pain, parenting, and grieving;
- Axis 2: the subject of the diagnosis, such as an individual, family, or group (such as the inability to cope within a community);

- Axis 3: judgment, such as compromised, decreased, delayed, disturbed, impaired, readiness;

- Axis 4: location, such as cerebral, kinesthetic, oral, renal, and tactile;

- Axis 5: age, such as fetus, neonate, infant, toddler preschool child, school age child, adolescent, adult, older adult;

- Axis 6: time, such as intermittent or continuous;

- Axis 7: status of the diagnosis, such as actual, health promotion, risk, wellness (Herdman, 2012).

Thus, the model is still doctor-oriented, and so problems will arise when trying to incorporate decisions based on nursing diagnosis (Scroggins, 2008).

Two models of assessment recommended by NANDA-I that can be linked to the diagnostic process include 11 functional patterns from Gordon and 13 divisions from Doengoes dan Moorhouse. Despite the recommendation of these two models, they are no longer popular. Therefore, a new model needs to be developed using the approach of function from Gordon or 13 divisions from Doengoes. Besides the identification of nursing diagnosis categories, information about surveillance of collaborative diagnoses is needed (Meyer et al. 2007, Kurashima et al. 2008).

This article describes a solution for complete form documentation integration of assessment and nursing diagnosis. Some of these solutions can be seen in Figure 1 taken from NANDA-I.

\section{The implementation strategy documenta- tion of assessment and nursing diagnosis}

An effective implementation strategy for Assessment and Nursing Diagnosis is needed, because this can increase the accuracy of nursing diagnoses. Standardization also can be done by computer, which can make nursing diagnosis more accurate and more rapid than manually completing a paper form (Wilkinson, 2006). Muller-Staub (2008) reported that guided clinical reasoning can improve the accuracy of nursing diagnosis. One solution integrates the assessment form and decisions related to the nursing diagnosis to allow nurses ease to identify problems and choose a nursing diagnosis that fits with the 13 Domains (Krogh, 2006) or is based on the 11 patterns of health function. Even this integration is not easy for nurses internationally because hospitals in different countries have different rules and varying levels of authority. This article provides a solution for nurses who work in hospitals in Indonesia and other countries with similar practices.

The model form that integrates assessment and nursing diagnosis refers to the 11 patterns of health function as shown in Figure 1. The advantage of this form is that nurses can immediately identify the problem in domain or pattern of health function directly without seeing the data in other patterns or places. Using the 11 functional health patterns can identify more than 146 nursing diagnoses. The nursing assessment form is designed for assessment of adult patients, not for children or groups. Diagnosis related to children and groups cannot be categorized for problem identification. The 11 functional health patterns are:

- Nutritional/metabolic pattern. After assessment, this pattern can identify 23 nursing diagnosis, such as autonomic dysreflexia, body temperature, fluid balance, hyperthermia, hypothermia, skin integrity, and impaired swallowing;

- Health-perception/health management pattern. This pattern can identify 20 nursing diagnosis, such as aspiration risk, falls risk, infection risk, latex allergy response, and trauma risk;

- Sleep/rest pattern. This pattern can identify three nursing diagnosis: sleep deprivation, sleep pattern disturbance, and readiness for enhancing sleep;

- Activity/exercise pattern. This pattern can identify 24 nursing diagnosis, such as activity intolerance, ineffective breathing 
pattern, decreased cardiac output, fatigue, impaired physical mobility, and bathing and hygiene;

- Elimination pattern. This pattern can identify 14 nursing diagnosis, such as constipation, diarrhea, fecal incontinence, and urinary incontinence;

- Value/belief pattern. This pattern can identify seven nursing diagnosis, such as decisional conflict, anticipatory grieving, dysfunctional grieving, and spiritual distress;

- Sexuality/reproduction pattern. This pattern can identify seven nursing diagnosis, such as sexual dysfunction and ineffective sexuality pattern;

- Self-perception/self-concept pattern. This pattern can identify seven nursing diagnoses, such as anxiety, disturbed body image, fear, and chronically low self-esteem;

- Cognitive/perceptual pattern. This pattern can identify seven nursing diagnosis, such as impaired verbal communication, acute or chronic confusion, impaired memory, nausea, acute pain, or olfactory disturbance;

- Copying/stress tolerance pattern. This pattern can identify 21 nursing diagnosis, such as defensive coping technique, ineffective coping, post-traumatic stress syndrome, selfmutilation, and suicide risk, etc;

- Role-relationship pattern. This pattern can identify approximately 16 nursing diagnosis, such as caregiver role strain, family processes interrupted, home maintenance impaired, loneliness risk for, parenting impaired, role conflict parental, role performance ineffective, social interaction impaired, social isolation, etc (Krogh, 2006, Herdman, 2012)

The health function pattern on the assessment form can immediately identify the correct diagnosis. Each pattern will show a diagnosis or any possible diagnoses, but if no data are available, it can be added to the other items, so validation of the data can be accomplished. The assessment form in this article does not include a separate physical assessment but integrates this immediately with each pattern of health function. Finally, it will allow nurses to complete an assessment and conduct a physical examination to facilitate the categorization of nursing diagnosis.

\section{Recommendation for nursing education}

- Nursing Students can conduct diagnoses accurately and quickly using this new assessment form to promote self-confidence in their daily nursing interventions.

- To facilitate nursing students in the application of nursing care documentation in nursing care

- To recognize early form of nursing care documentation

\section{Conclusion}

The integration of assessment and nursing diagnosis is more effective and easier, especially for home health care nurses, by providing information that should be assessed in every pattern of health function. This initial information can be used to assess additional data that helps make an accurate diagnosis. A feature that helps nurses feel confident during assessment is that the initial data is available as a part of the nursing diagnosis, which allows nurses to focus on the assessment.

\section{Acknowledgment}

The author are grateful to Muhammadiyah University of Surabaya for the financial support granted to cover the publication fee of this research article.

\section{References}

[1] Herdman,TH (2008). Nursing Diagnosis: Is It for a New Definition?.International Journal of Nursing Termnologies and Classifications, $19 \quad$ (1), $\quad 2-13 . \quad$ http://dx.doi.org/10.1111/j.1744618X.2007.00073.X.

[2] Herdman,TH (2008). Nursing Diagnosis: Definitions \& Classifications 2012-2014. USA: Wiley Blackwell Publishing.

[3] Karmawati, IA (2001). Nurses' Perception through the assessment documentation in hospital room RSUD Rebo Market Jakarta: Abstract Research, University of Indonesia. Available at: http://www.digilib.ui.ac.id/opac/themes/libri2 (accessed 17 May 2012)

[4] Kurashima, S, Kobayashi,K, Toyabe,S, Akazawa,K (2008). Accuracy and Efficiency of Computer-Aided Nursing Diagnosis.International Journal of Nursing Termnologies and Classifications, 19 (3), 95-301. http://dx.doi.org/10.1111/j.1744-618X.2008.00088.x.

[5] Kusumawaty, I (2001). The relationship between understanding of nursing process and function of supervision with documentation competencies of nursing process in hospital of Karya Bhakti Bogor: $A b-$ stract Research, University of Indonesia. Available at: http://www.digilib.ui.ac.id/opac/themes/libri2/detail.jsp?id=71558 (accessed 17 May 2012)

[6] Krogh, GV (2006). An Examination of the NANDA Interntional Taxonomy for Domain Completeness, Ontological Homogeneity, and Clinical Functionality.International Journal of Nursing Termnologies and Classifications, 19 (2), 65-75. http://dx.doi.org/10.1111/j.1744618X.2008.00083.X.

[7] Meyer, G (2007). Is it Time for a New Category of Nursing Diagnosis?.International Journal of Nursing Termnologies and Classifications, $180 \quad$ (2), $\quad 45-50 . \quad$ http://dx.doi.org/10.1111/j.1744618X.2007.00049.x.

[8] Muller-Staub, M, Needham,I, Odenbreit, M, Lavin,MA, Achterberg, TV (2007). Improved Quality of Nusring Documentation: Results of a Nursing Diagnoes, Interventions, and Outcomes Implementation Study.International Journal of Nursing Termnologies and Classifications, $18 \quad$ (1), $\quad 5-17 . \quad$ http://dx.doi.org/10.1111/j.1744618X.2007.00043.X.

[9] Muller-Staub, M, Needham,I, Odenbreit,M,Lavin,MA, Achterbag,TV (2008). Implementing nursing diagnosis effectively: cluster Randomized trial.Journal of Advanced Nursing, 63 (3), 291-301. http://dx.doi.org/10.1111/j.1365-2648.2008.04700.x.

[10] Muller-Staub M (2009). Evaluation of the Implementation of Nursing Diagnosis, Interventions, and Outcomes.International Journal of Nursing Termnologies and Classifications. 20 (1), 9-15. http://dx.doi.org/10.1111/j.1744-618X.2008.01108.x.

[11]Paganin, A, Moraes, MA, Pokorski, S, Rabelo, ER (2008). Factors that Inhibit the Use of Nursing Langeage.International Journal of Nursing Termnologies and Classifications. 19 (4), 150-157. http://dx.doi.org/10.1111/j.1744-618X.2008.00103.x.

[12] Scroggins, LM (2008). The Development Process for NANDA International Nursing Diagnoses. International Journal of Nursing Termnologies and Classifications, $19 \quad$ (2), 57-64. http://dx.doi.org/10.1111/j.1744-618X.2008.00082.x.

[13] Sumitra (2001). Related Factors with documentation of nursing assessment by nurses in hospital room RSUD Karawang : Abstract Research, Unversity of Indonesia. Available at: http://www.digilib.ui.ac.id/opac/themes/libri2/detail (accessed 17 May 2012).

[14]Widyantoro, W (2002). The relationship of the using of nursing information system with the completeness of nursing documentation in Fatmawati Hospital: Abstract Research, University of Indonesia. Available at: http://www.digilib.ui.ac.id/opac/themes/ libri2/detail.jsp?id=97376 (accessed 17 May 2012).

[15]Wilkinson,JM (2006). Nursing diagnosis handbool: with NIC Interventions and NOC Outcomes. New Jersey: Pearson Education, Inc. 


\begin{tabular}{|c|c|c|c|}
\hline \multicolumn{2}{|c|}{$\begin{array}{ll}\text { Patient's Name } & : \\
\text { Medical Dx } & : \\
\text { Age } & :\end{array}$} & \multicolumn{2}{|c|}{$\begin{array}{l}\text { Patient's Number/Medical Record:__ } \\
\text { Sex :__ Religion:_-_ } \\
\text { Address:___ }\end{array}$} \\
\hline \multirow{2}{*}{\multicolumn{4}{|c|}{$\begin{array}{l}\text { General Health : } \\
\text { Vital Signs: } \mathrm{T}: \_ \text {BP :__ RR :__ HR :__ }\end{array}$}} \\
\hline & & & \\
\hline 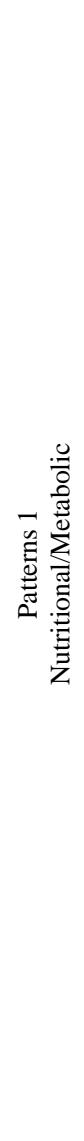 & 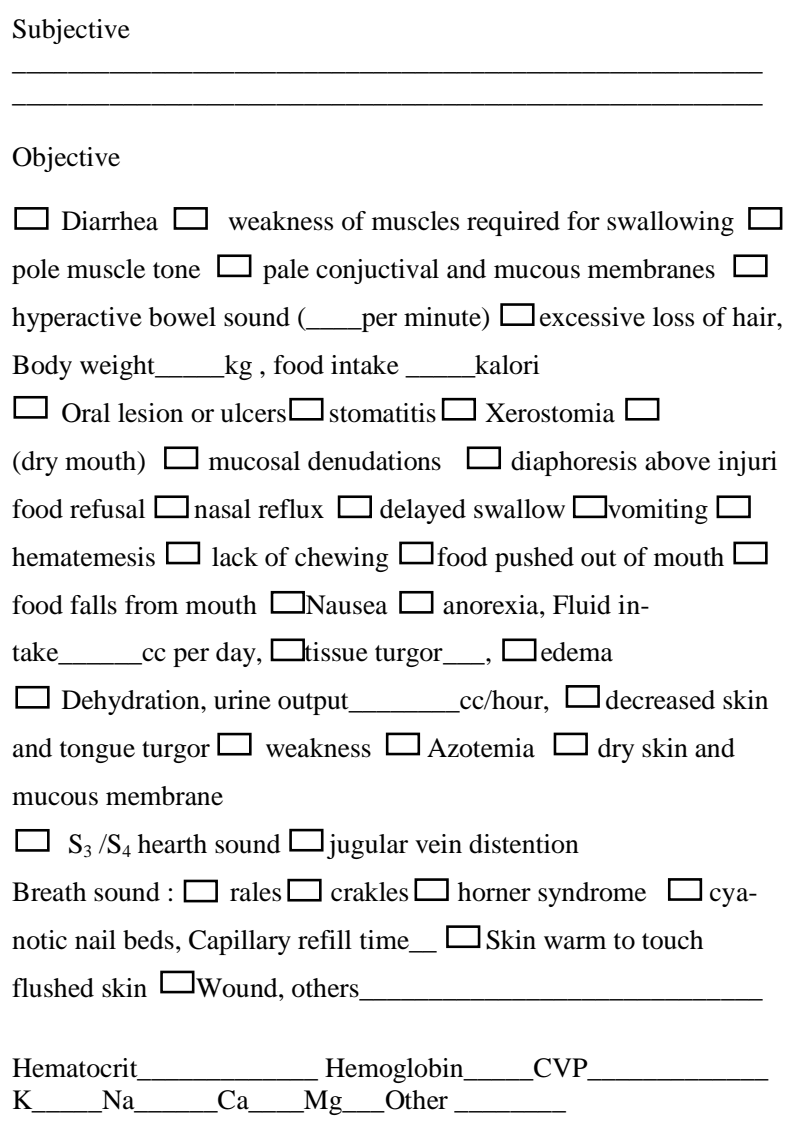 & 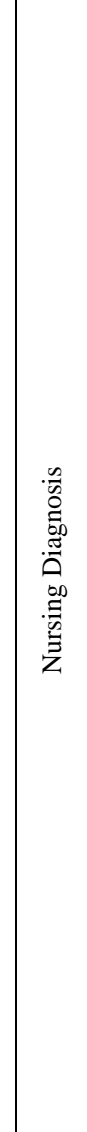 & $\begin{array}{l}1 \\
2 \\
3 \\
\text { ect. }\end{array}$ \\
\hline 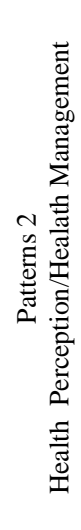 & $\begin{array}{l}\text { Subjective } \\
\\
\text { Objective } \\
\square \text { Trauma } \square \text { tube feeding } \square \text { increased gastric residual } \\
\square \text { depreased cough and gag reflexes } \\
\square \text { Impaired swallowing } \square \text { invasive procedures } \\
\text { Allergies food___allergies drug __ } \\
\text { Others__ } \\
\text { Leucocyte___ Trombocyte___ Others __ }\end{array}$ & 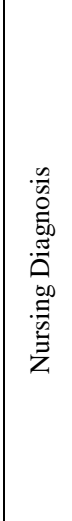 & $\begin{array}{l}1 \\
2 \\
3 \\
\text { ect. }\end{array}$ \\
\hline 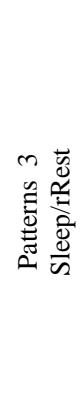 & $\begin{array}{l}\text { Subjective } \\
\\
\text { Objective } \\
\square \text { Lethargy } \square \text { irritability } \square \text { apathy } \square \text { restlesness } \\
\square \text { Hand tremors } \square \text { inability to concentrate, amount of } \\
\text { sleep___hour, } \square \text { insomnia, } \square \text { sleep onset greater than } 30 \text { min } \square \\
\text { impairment of normal pattern } \\
\square \text { Dark circles under eyes, others__ }\end{array}$ & 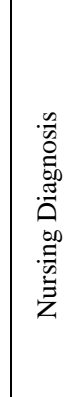 & $\begin{array}{l}1 \\
2 \\
3 \\
\text { ect. }\end{array}$ \\
\hline
\end{tabular}




\begin{tabular}{|c|c|c|c|}
\hline 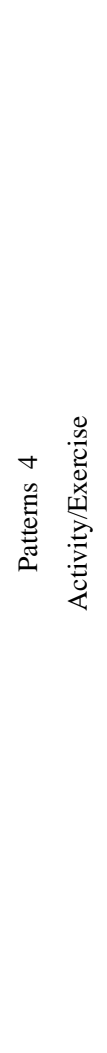 & 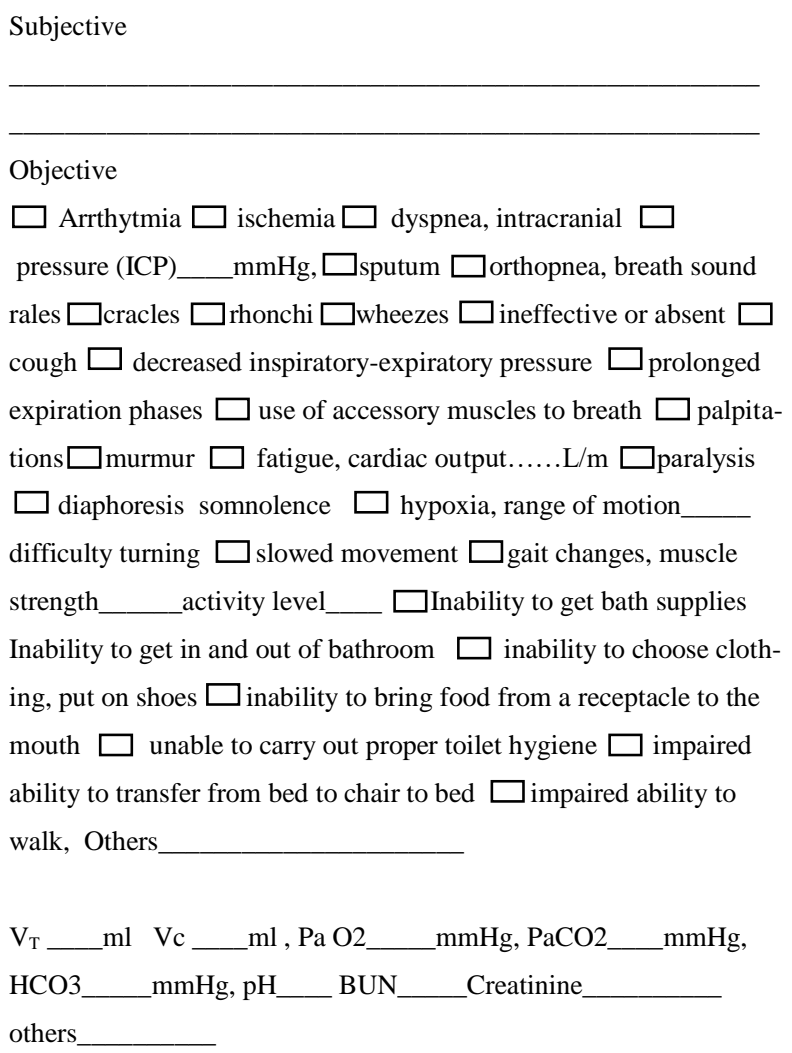 & & $\begin{array}{l}1 \\
2 \\
3 \\
\text { ect. }\end{array}$ \\
\hline 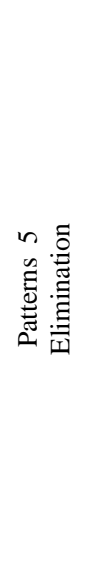 & $\begin{array}{l}\text { Subjective } \\
\\
\text { Objective } \\
\square \text { Distended abdomen } \square \text { dry, hard, formed stools } \\
\square \text { Dark or black or tarry stool } \square \text { change in bowel pattern } \square \\
\text { bright red bood with stool } \square \text { decreased volume of stool , frequency } \\
\text { of defecation___per day } \\
\square \text { At least three loose stools per day } \square \text { loss of urine before reach- } \\
\text { ing toilet, urinary frequency__ per day } \\
\square \text { Nocturia } \square \text { urinary urgency } \square \text { bladder distention } \square \text { over- } \\
\text { flow incontinence } \square \text { residual urine, others__ }\end{array}$ & & $\begin{array}{l}1 \\
2 \\
3 \\
\text { ect. }\end{array}$ \\
\hline 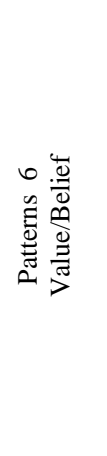 & $\begin{array}{l}\text { Subjective } \\
\\
\text { Objective } \\
\square \text { Delayed decision making } \square \text { sleep patterns } \square \text { Dream pat- } \\
\text { terns } \square \text { altered activity level } \square \text { altered libido } \square \text { difficulty tak- } \\
\text { ing } \square \text { inability pray } \square \text { inability to participate in religious activi- } \\
\text { ties } \square \text { refuses interactions with spiritual leaders } \square \text { disinterest in } \\
\text { reading spiritual literatur }\end{array}$ & & $\begin{array}{l}1 \\
2 \\
3 \\
\text { ect. }\end{array}$ \\
\hline
\end{tabular}




\begin{tabular}{|c|c|c|c|}
\hline 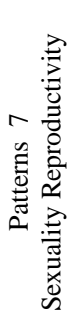 & $\begin{array}{l}\text { Subjective } \\
\\
\text { Objective } \\
\square \text { Alteration in orgasm or ejaculation } \square \text { change in sexual desire } \\
\text { impotence } \square \text { painful coitus } \square \text { vaginal dryness } \square \text { alterations in } \\
\text { achieving perceived sex role, others__ }\end{array}$ & 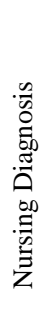 & +2 \\
\hline 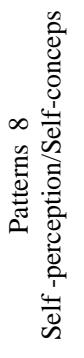 & $\begin{array}{l}\text { Subjective } \\
\\
\text { Objective } \\
\square \text { Pupil dilation } \square \text { change in body structure or function } \square \text { no } \\
\text { looking at body part } \square \text { dependent on others opinions } \square \text { lack of } \\
\text { eye contact } \square \text { nonassertive or passive } \square \text { behavior inconsistent } \\
\text { with values, others }\end{array}$ & 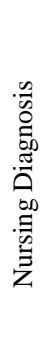 & $\begin{array}{l}1 \\
2 \\
3 \\
\text { ect. }\end{array}$ \\
\hline 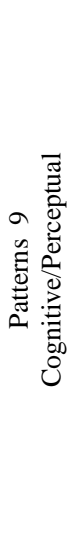 & $\begin{array}{l}\text { Subjective } \\
\\
\text { Objective } \\
\square \text { Disorientation } \square \text { aphasia } \square \text { dysphasia } \square \text { apraxia } \square \\
\text { dyslexia } \square \text { aphonia } \square \text { dyslalia } \square \text { dysarthria } \square \text { can not speak } \\
\square \text { agitations } \square \text { hallucinations } \square \text { inaccurate follow through of } \\
\text { instruction } \square \text { inaccurate performance on tests } \\
\square \text { facial mask of pain } \square \text { pain } \square \text { protective behavior } \\
\square \text { Reduced interaction with people } \square \text { poor concentration } \\
\square \text { memory deficit or problems } \\
\text { Others }\end{array}$ & 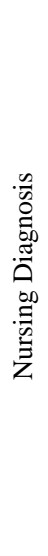 & $\begin{array}{l}1 \\
2 \\
3 \\
\text { ect. }\end{array}$ \\
\hline 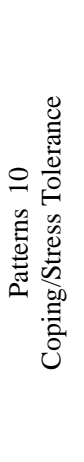 & $\begin{array}{l}\text { Subjective } \\
\text { Objective } \\
\square \text { Hypersensitive to slight or criticism } \square \text { difficulty in establishing } \\
\text { or maintaining relationships } \square \text { superior attitude toward others } \square \\
\text { refuses health care attention to the detriment of health } \square \text { aggres- } \\
\text { sion } \\
\square \text { Denial } \square \text { depression } \square \text { paranoia } \square \text { phobias } \\
\square \text { Shock } \square \text { dependence, others }\end{array}$ & 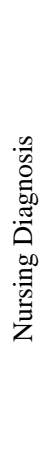 & $\begin{array}{l}1 \\
2 \\
3 \\
\text { ect. }\end{array}$ \\
\hline 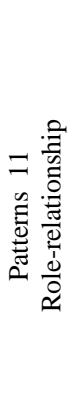 & $\begin{array}{l}\text { Subjective } \\
\\
\text { Objective } \\
\square \text { Dysfunctional interactions with peers, family, and other } \square \\
\text { discomfort in social situations } \square \text { inability to meet expectations of } \\
\text { others } \square \text { no eye contact } \square \text { Sad } \square \text { pessimistic attitude } \square \\
\text { inadequate knowledge } \square \text { inadequate coping } \square \text { inadequate role } \\
\text { competency and skills, others }\end{array}$ & 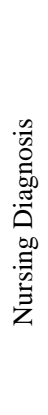 & $\begin{array}{l}1 \\
2 \\
3 \\
\text { ect. }\end{array}$ \\
\hline
\end{tabular}

Fig. 1: Model Integration of Assessment and Nursing Diagnosis Documentation. 